\title{
Infrared brazing of TiAl intermetallic using BAg-8 braze alloy
}

\author{
R.K. Shiue ${ }^{a}$, S.K. Wu ${ }^{\text {b,* }}$, S.Y. Chen ${ }^{b}$ \\ a Department of Materials Science and Engineering, National Dong Hwa University, Hualien 974, Taiwan, ROC \\ ${ }^{\mathrm{b}}$ Department of Materials Science and Engineering, National Taiwan University, Taipei 106, Taiwan, ROC
}

Received 4 September 2002; accepted 19 November 2002

\begin{abstract}
TiAl intermetallic alloy joined by infrared brazing using BAg-8 braze alloy was investigated. The microstructural evolution of the brazed joint, shear strength and reaction kinetics across the joint was comprehensively evaluated. According to the experimental observations, silver would not react with the TiAl substrate, but copper reacted vigorously with the TiAl, forming continuous reaction layer. The consumption of copper from molten braze during infrared brazing resulted in depletion of the copper content from the braze. Therefore, chemical composition of the braze deviated from $\mathrm{Ag}-\mathrm{Cu}$ eutectic into hypoeutectic with increased brazing time and/or temperature. Both $\mathrm{AlCuTi}$ and $\mathrm{AlCu}_{2} \mathrm{Ti}$ phase were observed at the interface between BAg- 8 and TiAl substrate for the specimen brazed at $950^{\circ} \mathrm{C}$. By increasing the brazing temperature and time, the growth rate of $\mathrm{AlCuTi}$ phase was much faster than that of $\mathrm{AlCu}_{2} \mathrm{Ti}$ phase. The maximum shear strength achieved $343 \mathrm{MPa}$ for the specimen infrared brazed at $950^{\circ} \mathrm{C}$ for $60 \mathrm{~s}$. Further increasing the brazing time resulted in excessive growth of brittle AlCuTi reaction layer, which greatly deteriorated the shear strength of the joint.
\end{abstract}

(C) 2003 Acta Materialia Inc. Published by Elsevier Science Ltd. All rights reserved.

Keywords: Infrared brazing; Titanium aluminide; Microstructure; Bonding strength test; BAg-8 braze alloy

\section{Introduction}

Titanium aluminides play an important role in the recent development of new materials for structural applications on the basis of intermetallic phases [1-5]. Furthermore, intensive activity has been presented on the research and development of high-temperature structural intermetallics during

* Corresponding author. Tel.: +886-2-2363-7846; fax: +8862-2363-4562.

E-mail address: skw@ccms.ntu.edu.tw (S.K. Wu). the last two decades [6-11]. The TiAl-based alloy is one of the most advanced intermetallics, and has successfully demonstrated its potential for aerospace and automotive applications such as turbine blades, exhaust valves and turbo charger rotors $[3,12]$. The primary advantages of titanium aluminides are low density, high specific strength as well as high stiffness and strength at elevated temperature compared to conventional titanium alloys [3]. Therefore, they are considered as potential replacements for superalloys in aircraft turbine engines, airframes and automotive engines.

Titanium aluminides can be fabricated by tra- 
ditional casting and ingot metallurgy technology, but the processing cost tends to be high due to a high degree of segregation that occurs during the solidification [3]. In addition to the conventional casting, there are many other manufacturing processes available for production of TiAl-based intermetallics, e.g. powder metallurgy, hot isostatic pressing (HIP), near net shape technology, direct laser fabrication, etc $[3,13]$. Besides these manufacturing techniques for TiAl-based intermetallics, the joining of titanium aluminides is one of the most important processes in application of this material. The bonding of titanium aluminides is more difficult than most other structural alloys due to the high reactivity of $\mathrm{TiAl}$ and the tendency to form fragile intermetallic phase(s) across the joint interface. In addition, the high reactivity of TiAl intermetallics results in ready formation of the oxide layer and deterioration of the wettability of the joined surfaces $[14,15]$. In addition, the formation of brittle intermetallic reaction layer(s) adjacent to the joined interface is detrimental to its bonding strength. Successful joining of TiAl-based intermetallics can be performed by welding, diffusion bonding, brazing, etc [16-21]. Vacuum brazing is a good choice for bonding materials difficult to join by traditional welding process. It is reported that silver, copper, gold, titanium and nickel base braze alloys have been used in vacuum brazing of TiAl-based intermetallics [16,17]. However, both microstructural evolution and strength evaluation of the brazed TiAl joint need further study.

Compared with conventional vacuum furnace brazing, infrared vacuum brazing is characterized by very rapid thermal cycles [22]. There are many successful joints that are reported in the literature using this novel technique [22-24]. The heating rate of a traditional vacuum brazing furnace is usually below $50^{\circ} \mathrm{C} / \mathrm{min}$, which is much slower than that of an infrared furnace. The molten braze can react simultaneously with the substrate at temperatures above the liquidus of braze alloy and below the brazing temperature. Consequently, the initial stage of reaction at the interface between the braze alloy and substrate cannot be analyzed precisely using furnace brazing due to the insufficient heating rate during brazing. On the contrary, the maximum heating rate of an infrared brazing furnace is as high as $3000^{\circ} \mathrm{C} / \mathrm{min}$ [22]. With the aid of infrared brazing, very early stage interfacial reaction kinetics of the brazed joint can be accurately examined by the experiment. Therefore, infrared brazing is a powerful tool for the analysis of early stages of interfacial reaction in joints.

It is well known that pure silver can easily braze most titanium alloys $[25,26]$. Furthermore, it is reported that many Ag-based braze alloys can also be used for brazing TiAl intermetallics $[16,17]$. The melting point of pure silver is $961^{\circ} \mathrm{C}$, and it can be greatly decreased by alloying copper into silver matrix. For instance, the melting point of a $\mathrm{Ag}-\mathrm{Cu}$ eutectic alloy is as low as $780^{\circ} \mathrm{C}$ [27]. A lower brazing temperature is preferred for most brazing processes, so the $\mathrm{Ag}-\mathrm{Cu}$ eutectic braze alloy was chosen here as the filler metal for infrared brazing of TiAl intermetallics.

The current investigation concentrates on a new approach to joining TiAl by infrared brazing using BAg-8 braze alloy. The microstructural evolution, shear strength and reaction kinetics across the brazed joint are comprehensively studied to access the relation between the microstructure and the joint performance.

\section{Experimental procedures}

The master alloy with the nominal composition $\mathrm{Ti}_{50} \mathrm{Al}_{50}$ (in at\%) was prepared by vacuum arc remelting of high purity ( $>99.99$ wt $\%$ ) titanium rods and aluminum pellets. Both titanium rods and aluminum pellets were cleaned by $1 \mathrm{HF}-15 \mathrm{HNO}_{3}{ }^{-}$ $64 \mathrm{H}_{2} \mathrm{O}$ (in $\mathrm{ml}$ ) and saturated $\mathrm{NaOH}$ solution prior to vacuum arc remelting, respectively. Vacuum arc remelting was performed at least six times, and the final weight loss of the master alloy was less than $0.1 \mathrm{wt}$ pct. The master alloy was homogenized at $950^{\circ} \mathrm{C}$ for $100 \mathrm{~h}$ to reduce segregation of the alloy. BAg-8 foil purchased from Lucas-Milhaupt Inc. was used as brazing filler metal. According to the AWS (American Welding Society) specification of silver-base braze alloys, the chemical composition of BAg-8 alloy in weight percent is (71-73) silver and copper balance, and its eutectic temperature is $780^{\circ} \mathrm{C}[27,28]$. The thickness of the braze alloy tape was $100 \mu \mathrm{m}$ throughout the experiment. 
As mentioned above, compared with conventional furnace brazing, infrared brazing has much faster thermal cycles [22]. In addition, higher infrared brazing temperature will do less damage to the base metal. Since a high brazing temperature can significantly speed up the microstructural evolution of the brazed joint, higher brazing temperatures were chosen for this study. Infrared brazing was performed in a vacuum of $8 \times 10^{-5} \mathrm{mbar}$, and the heating rate was set at $900^{\circ} \mathrm{C} / \mathrm{min}$ throughout the experiment. All specimens were preheated to $500^{\circ} \mathrm{C}$ for $600 \mathrm{~s}$ before they were heated up to the brazing temperature. Because there was a time delay between the actual specimen temperature and programmer temperature, so time compensation was necessary in the experiment [22-24]. The brazing time specified in the test was the actual specimen holding time [22]. Table 1 summarizes all process variables used in infrared brazing of TiAl intermetallics.

The size of brazed specimens was $10.0 \times 10.0$ $\times 2.5 \mathrm{~mm}$. All joined surfaces were polished by $\mathrm{SiC}$ papers up to grit 1200 , and ultrasonically cleaned by acetone prior to infrared brazing. The area of filler metal foil was approximately the same as that of base metal. To enhance the absorption of infrared rays, a graphite fixture was used during brazing, as described in a previous study [24]. Specimens were sandwiched between two graphite plates, and an R-type thermal couple was inserted into the upper graphite plate, in contact with the brazed specimen.

Table 1

Summary of process variables used in the experiment

\begin{tabular}{|c|c|c|c|c|c|}
\hline $\begin{array}{l}\text { Brazing } \\
\text { time }\end{array}$ & $900^{\circ} \mathrm{C}$ & $950^{\circ} \mathrm{C}$ & $1000^{\circ} \mathrm{C}$ & $1050^{\circ} \mathrm{C}$ & $1150^{\circ} \mathrm{C}$ \\
\hline $15 \mathrm{~s}$ & & M & & $\mathrm{M}$ & $\mathrm{M}$ \\
\hline $30 \mathrm{~s}$ & & $\mathrm{M} / \mathrm{S}$ & & $\mathrm{M}$ & $\mathrm{M}$ \\
\hline $45 \mathrm{~s}$ & & M & & M & M \\
\hline $60 \mathrm{~s}$ & & $\mathrm{M} / \mathrm{S}$ & & M & M \\
\hline $90 \mathrm{~s}$ & & $\mathrm{M} / \mathrm{S}$ & & M & M \\
\hline $120 \mathrm{~s}$ & & $\mathrm{M} / \mathrm{S}$ & & M & $\mathrm{M}$ \\
\hline $180 \mathrm{~s}$ & $\mathrm{M}$ & $\mathrm{M} / \mathrm{S}$ & $\mathrm{M}$ & $\mathrm{M}$ & $\mathrm{M}$ \\
\hline
\end{tabular}

M, metallographic observation specimen; $\mathrm{S}$, shear test specimen.
Fig. 1 shows the shear test specimen used in this experiment [24]. The shaded area is TiAl base metal, and the outer part of the layout is the graphite fixture used in the infrared brazing. The two bold black lines $1.5 \mathrm{~mm}$ wide in the middle of the graph indicate the braze filler alloy, and the specimen is sandwiched between two graphite plates. A shear test was performed by the Shimadzu AG-10 universal testing machine to evaluate the bonding strength of the infrared brazed joint. The brazed specimen was compressed by a universal testing machine with a constant speed of $1 \mathrm{~mm} / \mathrm{min}$. Microhardness measurements were made using a microhardness tester (Akashi MVK-E II) with a load of $10 \mathrm{~g}$ and a duration time of $15 \mathrm{~s}$. The experimental data were averaged from 10 measurements of each brazing condition. The structural analysis of the fractured surface after shear test was performed using a Philips PW1710 X-Ray diffractometer (XRD), and $\mathrm{Cu} \mathrm{K}_{\alpha}$ was chosen as the $\mathrm{X}$-ray source. The cross section of the brazed specimens was examined using either LEO 1530 field emission scanning electron microscope (FESEM) or Philips XL-30 scanning electron microscope (SEM) equipped with an energy dispersive spectrometer (EDS). Quantitative chemical analysis was performed using a JEOL JXA8600SX electron probe microanalyzer (EPMA) equipped with a wavelength dispersive spectrometer (WDS), operating with spot size of $1 \mu \mathrm{m}$, and operation voltage of $15 \mathrm{kV}$.

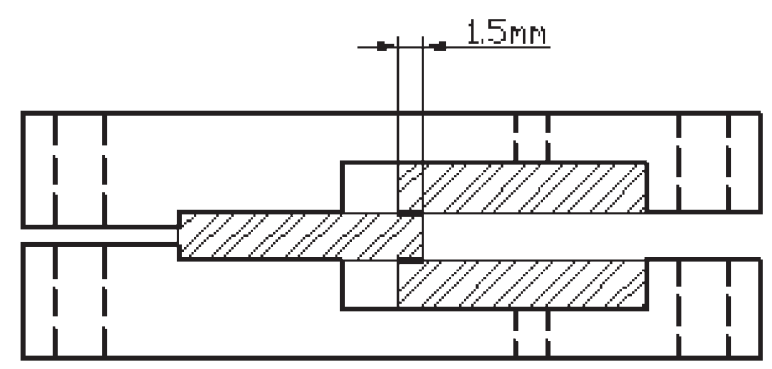

Fig. 1. Schematic diagram of the shear test specimen. 


\section{Results and discussion}

\subsection{Microstructural evolution of the infrared brazed TiAl/BAg-8/TiAl joint}

Fig. 2 shows the SEM backscattered electron images (BEIs) of TiAl/BAg-8/TiAl specimen infrared brazed at $950^{\circ} \mathrm{C}$ for $30,45,60,90,120$ and $180 \mathrm{~s}$. Because the chemical composition of
BAg-8 braze is $\mathrm{Ag}-\mathrm{Cu}$ eutectic, it is anticipated that the braze is mainly comprised of Ag-Cu eutectic structure, as shown in the figure. The microstructure of the brazed joint changes gradually with increased the brazing time. In addition, there are reaction layers between the braze and TiAl substrate, whose thickness increases with prolonged the brazing time. The growth of the interfacial reaction layer results in the loss of element(s) in

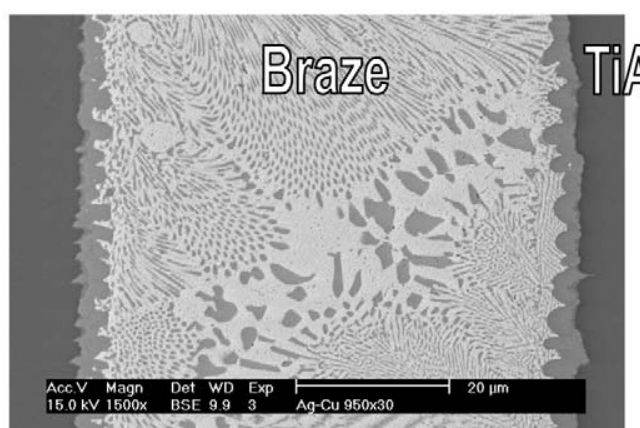

(a)

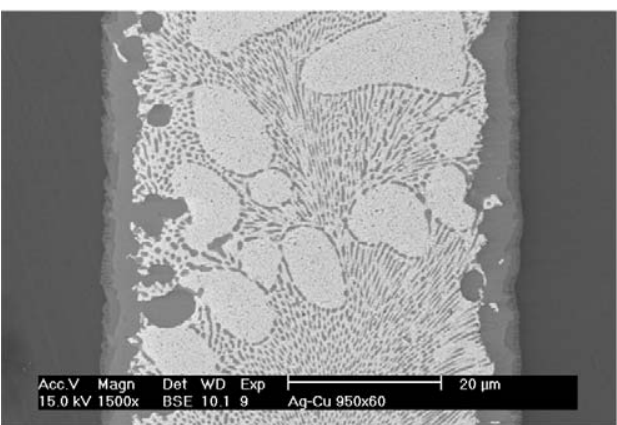

(c)

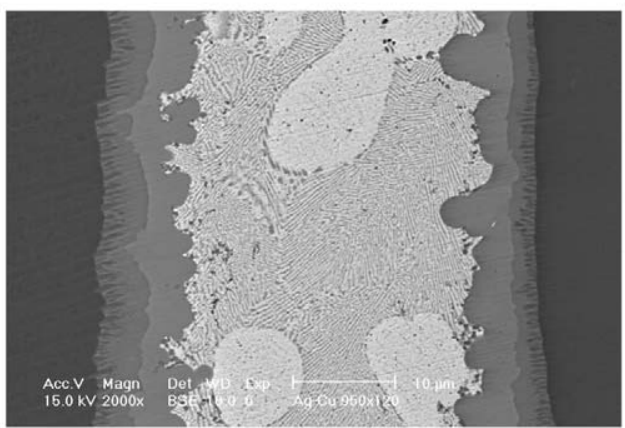

(e)

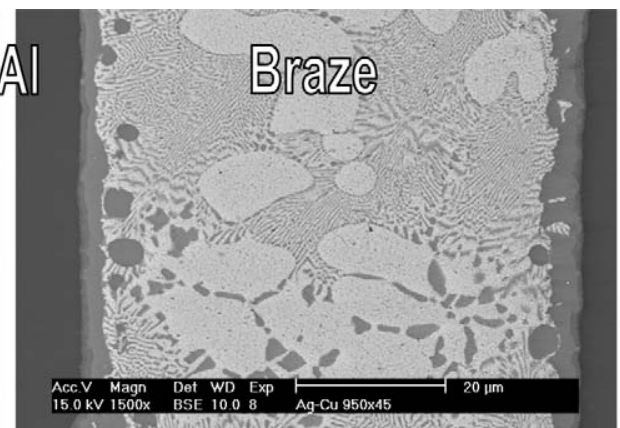

(b)

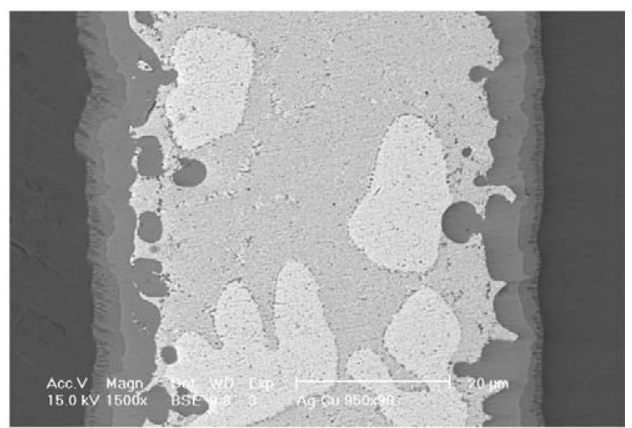

(d)

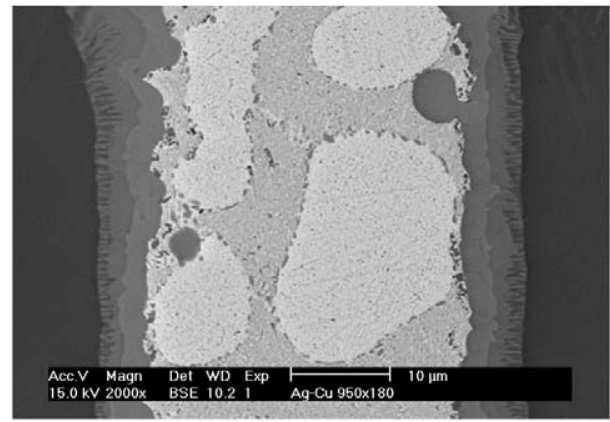

(f)

Fig. 2. SEM BEIs of the TiAl/BAg-8/TiAl specimen brazed at $950^{\circ} \mathrm{C}$ for (a) 30 (b) 45 (c) 60 (d) 90 (e) 120 and (f) $180 \mathrm{~s}$. 
the braze alloy, so the microstructure of the braze on interfacial reaction layer is also changed with increased brazing time.

Fig. 3 illustrates both the SEM BEI and EPMA chemical analysis results of TiAl/BAg-8/TiAl specimens brazed at $950^{\circ} \mathrm{C}$ for $120 \mathrm{~s}$. The substrate is TiAl, as marked by A in Fig. 3, and it is alloyed with small amounts of silver and copper due to the interdiffusion between the braze alloy and substrate. As described earlier, the microstructure of BAg-8 prior to infrared brazing is an eutectic structure. According to the experimental observation, silver will not react with TiAl substrate, but copper will react vigorously with the $\mathrm{TiAl}$, forming the continuous reaction layer(s). The consumption of copper from molten braze during infrared brazing results in depletion of the copper content in braze. Therefore, chemical composition of the braze deviates from $\mathrm{Ag}-\mathrm{Cu}$ eutectic into hypoeutectic. The primary Ag-rich phase, as marked by D in Fig. 3, is observed throughout the brazement after infrared brazing. According to binary alloy phase diagrams, the solubility of aluminum in silver matrix at room temperature is 10 at pct, and the solubility of titanium in silver matrix at room temperature is 2 at pct [29]. Silver can form a solid solution with

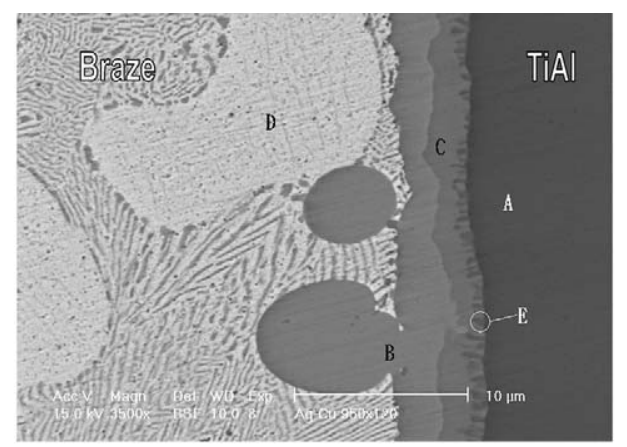

\begin{tabular}{|c|c|c|c|c|c|}
\hline $\mathrm{Wt} \% / \mathbf{A t} \%$ & $\mathrm{~A}$ & $\mathrm{~B}$ & $\mathrm{C}$ & $\mathrm{D}$ & $\mathrm{E}$ \\
\hline $\mathrm{Ti}$ & $64.3 / \mathbf{5 0 . 3}$ & $23.5 / \mathbf{2 6 . 5}$ & $34.7 / \mathbf{3 3 . 8}$ & $0.5 / \mathbf{1 . 0}$ & $51.6 / \mathbf{4 6 . 9}$ \\
\hline $\mathrm{Al}$ & $35.5 / \mathbf{4 9 . 5}$ & $8.5 / \mathbf{1 7 . 1}$ & $19.0 / \mathbf{3 2 . 9}$ & $2.7 / \mathbf{9 . 7}$ & $22.24 / \mathbf{3 5 . 9}$ \\
\hline $\mathrm{Cu}$ & $0.1 / \mathbf{0 . 1}$ & $63.7 / \mathbf{5 4 . 2}$ & $43.8 / \mathbf{3 2 . 2}$ & $3.0 / \mathbf{4 . 6}$ & $24.01 / \mathbf{1 6 . 3}$ \\
\hline $\mathrm{Ag}$ & $0.1 / \mathbf{0 . 1}$ & $4.3 / \mathbf{2 . 2}$ & $2.5 / \mathbf{1 . 1}$ & $93.8 / \mathbf{8 4 . 7}$ & $2.15 / \mathbf{0 . 9}$ \\
\hline $\begin{array}{c}\text { Possible } \\
\text { Phase }\end{array}$ & $\mathrm{TiAl}$ & $\mathrm{AlCu}_{2} \mathrm{Ti}$ & $\mathrm{AlCuTi}$ & $\begin{array}{c}\text { Primary } \\
\text { Ag-rich }\end{array}$ & --- \\
\hline
\end{tabular}

Fig. 3. SEM BEI and EPMA chemical analysis results of the TiAl/BAg-8/TiAl specimens brazed at $950^{\circ} \mathrm{C}$ for $120 \mathrm{~s}$. copper up to 5 at pct at $600^{\circ} \mathrm{C}$ [29]. It is reasonable that the primary Ag-rich phase is alloyed with aluminum, titanium and copper. However, the volume fraction of the primary Ag-rich phase is significantly increased as the brazing time is increased from 30 to $180 \mathrm{~s}$. Meanwhile, the volume fraction of eutectic Ag-Cu phase is decreased, as demonstrated in Fig. 2.

At least two continuous reaction layers can be found in Fig. 3 as marked by B and C. Since the reaction layer primarily consists of aluminum, copper and titanium, an $\mathrm{Al}-\mathrm{Cu}-\mathrm{Ti}$ ternary alloy phase diagram is selected to explain the phase evolution at the reaction layer. Fig. 4(a) shows a liquidus projection of Al-Cu-Ti ternary alloy phase diagram, and the important reaction schemes are also included [30]. Fig. 4(b) is its isothermal section at $500^{\circ} \mathrm{C}[30]$. There are many $\mathrm{Al}-\mathrm{Cu}-\mathrm{Ti}$ ternary intermetallics as illustrated in Fig. 4(a). Based on the EPMA analyses shown in Fig. 3, the stoichiometry of phase $\mathrm{B}$ is close to that of $\mathrm{AlCu}_{2} \mathrm{Ti}$ in Fig. 4(a) [30]. Similarly, Tetsui suggests that an $\mathrm{AlM}_{2} \mathrm{Ti}$ type hard B2 intermetallic is formed inside brazed joints and at the boundaries to TiAl as a result of reactions of TiAl with copper, nickel or gold from the brazing filler [17]. This suggestion is consistent with our experimental observation.

$\mathrm{AlCu}_{2} \mathrm{Ti}$ phase is the only continuous reaction layer at the early stages of infrared brazing, such as $30 \mathrm{~s}$ at $950^{\circ} \mathrm{C}$ brazing (Fig. 2(a)). With increased brazing time, phase $\mathrm{C}$ is formed between $\mathrm{AlCu}_{2} \mathrm{Ti}$ reaction layer and $\mathrm{TiAl}$ substrate. The stoichiometry of phase $\mathrm{C}$ is very close to AlCuTi solid solution with minor silver. According to $\mathrm{Al}-\mathrm{Cu}-\mathrm{Ti}$ ternary alloy phase diagram, the AlCuTi phase can be expressed as $\operatorname{Ti}\left(\mathrm{Cu}_{1-\mathrm{x}} \mathrm{Al}_{\mathrm{x}}\right)_{2}$, where $x$ is between 0.45 and 0.70 [30]. It can also be observed that the growth rate of AlCuTi phase is much faster than that of $\mathrm{AlCu}_{2} \mathrm{Ti}$ phase, as demonstrated in Fig. 2 (b-f). Fig. 5 displays the high magnification SEM BEI of the interface between TiAl substrate and BAg- 8 braze after $950^{\circ} \mathrm{C}$ brazing for $120 \mathrm{~s}$. It can be noted that a lamellar phase exists in AlCuTi phase close to the interface. However, its chemical composition can not be quantified precisely due to the limitation of EPMA's lateral resolution.

The brazing temperature was further increased to speed up the microstructural evolution of the 
(a)

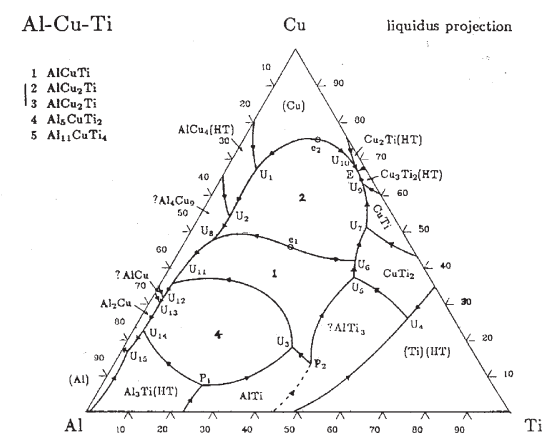

(b) Al-Cu-Ti

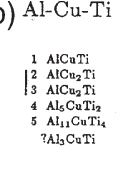

$500^{\circ} \mathrm{C}(773 \mathrm{~K})$

Reaction Scheme

$\mathrm{Al}-\mathrm{Cu}-\mathrm{Ti}$
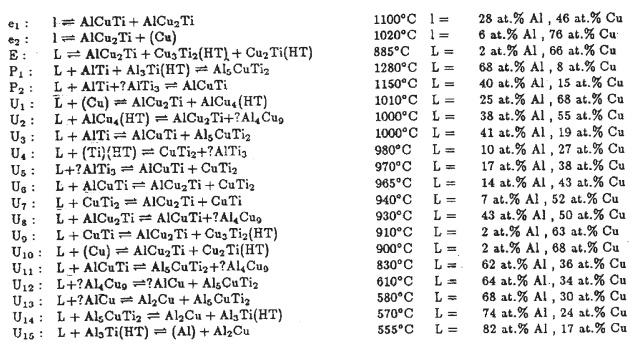

Fig. 4. Al-Cu-Ti ternary alloy phase diagrams (a) liquidus projection, (b) isothermal section at $500^{\circ} \mathrm{C}[30]$.

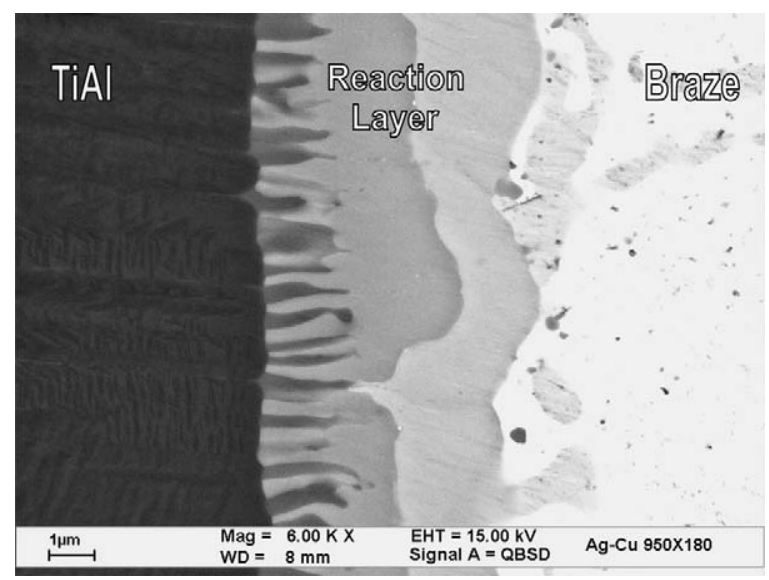

Fig. 5. High magnification FESEM BEI of the interface between TiAl substrate and BAg- 8 braze after $950^{\circ} \mathrm{C}$ brazing for $120 \mathrm{~s}$.

joint. Fig. 6 shows the SEM BEIs of TiAl/BAg$8 / \mathrm{TiAl}$ specimen brazed at $1050^{\circ} \mathrm{C}$ for $30,45,60$, 90, 120 and $180 \mathrm{~s}$. The morphology of the brazed joint is very different from that brazed at $950^{\circ} \mathrm{C}$. In Fig. 6, the $\mathrm{Ag}-\mathrm{Cu}$ eutectic phase has vanished from the braze. As discussed earlier, the disappearance of eutectic $\mathrm{Ag}-\mathrm{Cu}$ phase from the braze is primarily caused by further consumption of copper from the braze due to growth of the reaction layer. In this joint, a very thick reaction layer can be observed, and the longer the brazing time, the thicker the reaction layer (Fig. 6).

Fig. 7 shows the SEM BEI and EPMA chemical analysis of selected areas for the specimen infrared brazed at $1050^{\circ} \mathrm{C}$ for $30 \mathrm{~s}$. The Ag-rich phase (marked by E) in the braze matrix is rapidly decreased by increasing the brazing time. In contrast to the specimens brazed at $950^{\circ} \mathrm{C}$, an $\mathrm{Al}_{4} \mathrm{Cu}_{9}$ phase marked by $\mathrm{A}$ was found in the braze, with at least three interfacial reaction layers, as demonstrated in Fig. 7. Phase $\mathrm{C}$ can be identified as $\mathrm{AlCuTi}$, and it has the fastest growth rate among all interfacial layers. The fast growth of the AlCuTi interlayer results in disappearance of the transient $\mathrm{Al}_{4} \mathrm{Cu}_{9}$ phase in the joint. Similar to this result, phase $\mathrm{B}$ can be classified as $\mathrm{AlCu}_{2} \mathrm{Ti}$, and the amount of phase $\mathrm{B}$ is decreased with longer brazing time, as illustrated in Fig. 6. The decrease of 


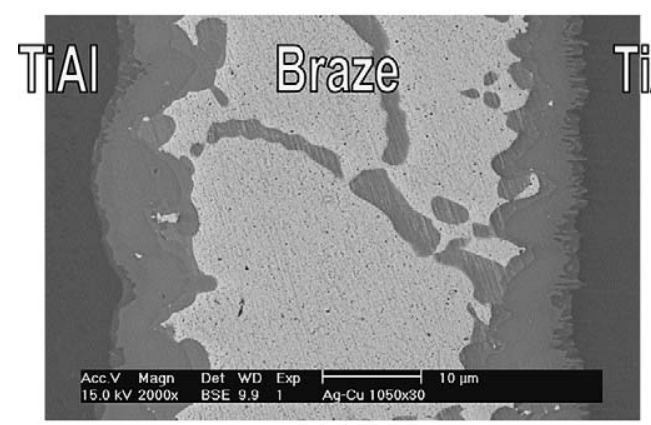

(a)

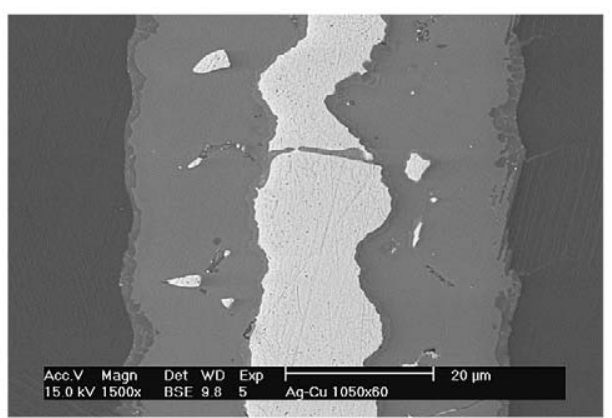

(c)

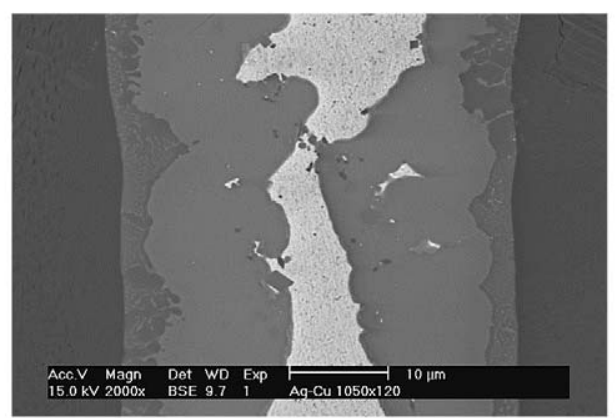

(e)

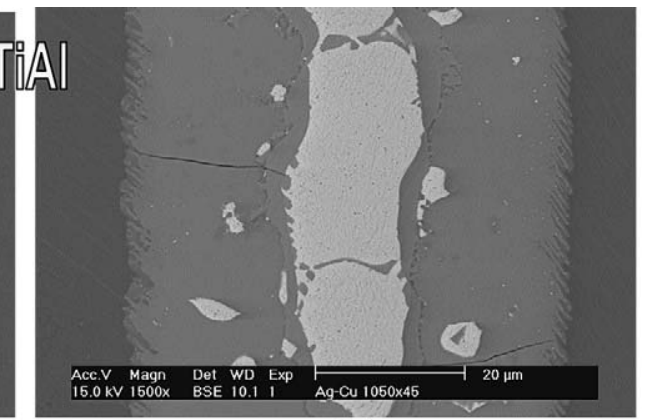

(b)

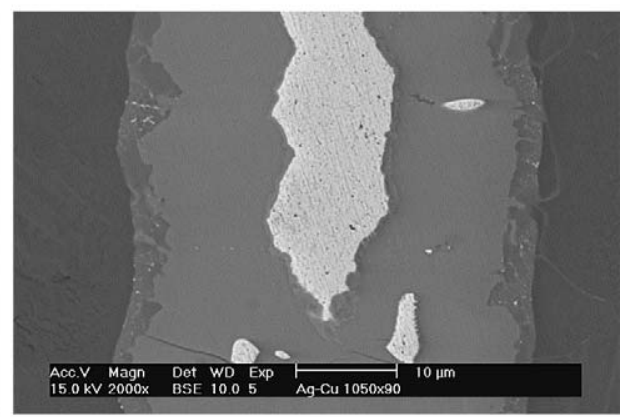

(d)

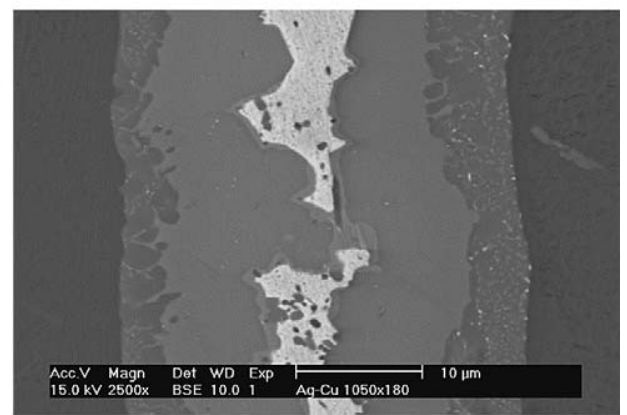

(f)

Fig. 6. SEM BEIs of the TiAl/BAg-8/TiAl specimen brazed at $1050^{\circ} \mathrm{C}$ for (a) 30 (b) 45 (c) 60 (d) 90 (e) 120 and (f) $180 \mathrm{~s}$.

$\mathrm{AlCu}_{2} \mathrm{Ti}$ phase can be attributed to both the depletion of copper in the braze and the rapid growth of AlCuTi phase. It is also noteworthy that a continuous $\mathrm{Ti}_{3} \mathrm{Al}$ layer is identified, as marked by $\mathrm{D}$ in Fig. 6, and the formation of $\mathrm{Ti}_{3} \mathrm{Al}$ interfacial layer will be discussed in the following section.

Fig. 8 displays the SEM BEIs of $\mathrm{TiAl} / \mathrm{BAg}$ $8 / \mathrm{TiAl}$ specimens brazed at $1150^{\circ} \mathrm{C}$ for $15,30,45$, 90,120 and $180 \mathrm{~s}$. The microstructure of the specimens infrared brazed at $1150^{\circ} \mathrm{C}$ is very different from the aforementioned results. Fig. 9 shows the
FESEM BEI and EPMA chemical analysis results of $\mathrm{TiAl} / \mathrm{BAg}-8 / \mathrm{TiAl}$ specimens brazed at $1150^{\circ} \mathrm{C}$ for $45 \mathrm{~s}$. Here, AlCuTi is the major phase in the joint, as marked by B in Fig. 8, and the amount of Ag-rich phase (marked by $\mathrm{C}$ ) is greatly decreased. In addition, $\mathrm{Ti}_{3} \mathrm{Al}$ is also observed across the joint. In addition, a crack is found, as shown in Fig. 8(e), which is caused by cutting the brazed sample prior to metallographic inspection. This joint is very fragile due to the extensive existence of brittle intermetallics in the joint. 


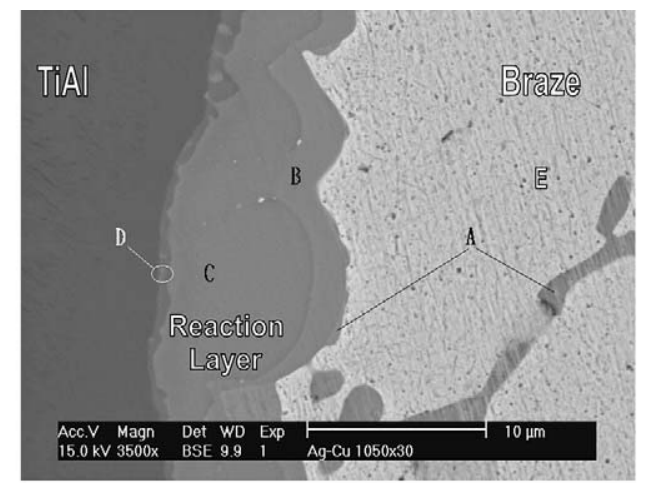

\begin{tabular}{|c|c|c|c|c|c|}
\hline $\mathrm{Wt} \% / \mathbf{A t} \%$ & $\mathrm{~A}$ & $\mathrm{~B}$ & $\mathrm{C}$ & $\mathrm{D}$ & $\mathrm{E}$ \\
\hline $\mathrm{Ti}$ & $0.5 / \mathbf{0 . 5}$ & $24.1 / \mathbf{2 6 . 6}$ & $34.6 / \mathbf{3 4 . 2}$ & $67.1 / \mathbf{6 0 . 3}$ & $0.4 / \mathbf{0 . 8}$ \\
\hline $\mathrm{Al}$ & $13.1 / \mathbf{2 8 . 2}$ & $11.3 / \mathbf{2 1 . 9}$ & $18.4 / \mathbf{3 2 . 3}$ & $20.9 / 33.4$ & $0.8 / \mathbf{2 . 8}$ \\
\hline $\mathrm{Cu}$ & $81.9 / \mathbf{6 9 . 2}$ & $59.4 / \mathbf{4 8 . 9}$ & $42.0 / \mathbf{3 1 . 3}$ & $5.6 / 3.8$ & $6.1 / \mathbf{9 . 7}$ \\
\hline $\mathrm{Ag}$ & $4.5 / \mathbf{2 . 1}$ & $5.2 / \mathbf{2 . 6}$ & $5.0 / \mathbf{2 . 2}$ & $6.4 / \mathbf{2 . 5}$ & $92.7 / \mathbf{8 6 . 7}$ \\
\hline $\begin{array}{c}\text { Possible } \\
\text { Phase }\end{array}$ & $\mathrm{Al}_{4} \mathrm{Cu}_{9}$ & $\mathrm{AlCu}_{2} \mathrm{Ti}$ & $\mathrm{AlCuTi}$ & $\mathrm{Ti}_{3} \mathrm{Al}$ & Ag-rich \\
\hline
\end{tabular}

Fig. 7. SEM BEI and EPMA chemical analysis results of the TiAl/BAg-8/TiAl specimens brazed at $1050^{\circ} \mathrm{C}$ for $30 \mathrm{~s}$.

\subsection{The reaction path of the infrared brazed joint}

The TiAl substrate is partially dissolved into the molten braze during infrared brazing, so the molten braze close to TiAl interface is rich in titanium and aluminum contents. The degree of the substrate dissolution into the molten braze is strongly temperature and time dependent. For the specimens brazed at a fixed temperature, prolonging the brazing time results in enhanced dissolution of the substrate into molten braze. Based on the experimental observation, the reaction layers are mainly comprised of titanium, aluminum and copper, so silver in the molten braze has little effect on the interfacial reaction. When the cooling path is close to equilibrium, the $\mathrm{Al}-\mathrm{Cu}-\mathrm{Ti}$ liquidus projection can provide the first approximation of the equilibrium phase(s) in the brazed joint. First, there is a binary eutectic reaction $\left(\mathrm{e}_{2}\right)$ at $1020^{\circ} \mathrm{C}$ in Fig. 4(a), as shown below [30]:

$$
\mathrm{L} \leftrightarrow \mathrm{AlCu}_{2} \mathrm{Ti}+(\mathrm{Cu})
$$

It is important to note that the chemical composition of liquid in equation (1) is $76 \mathrm{Cu}, 6 \mathrm{Al}$ and
$18 \mathrm{Ti}$ in at pct. According to our experimental results, it is the $\mathrm{Ag}-\mathrm{Cu}$ eutectic phase, instead of copper, which is observed after infrared brazing due to the existence of silver in BAg-8 braze alloy. Moreover, the use of BAg- 8 braze alloy can greatly decrease the melting point of the braze alloy.

For the specimen brazed at $950^{\circ} \mathrm{C}$, the dissolution of TiAl is not prominent at the initial stage of infrared brazing, e.g. 30 s. Here, the molten braze dissolves only little titanium and aluminum during infrared brazing for a short time, so it is consistent with the liquid composition in equation (1). Based on equation (1), the $\mathrm{AlCu}_{2} \mathrm{Ti}$ phase is formed during solidification of the liquid, and the $\mathrm{AlCu}_{2} \mathrm{Ti}$ phase is observed upon cooling of the molten braze as illustrated in Fig. 2(a) and (b). The irregular interface between the braze and the $\mathrm{AlCu}_{2} \mathrm{Ti}$ phase demonstrates that the $\mathrm{AlCu}_{2} \mathrm{Ti}$ phase was solidified from liquid phase. With increasing the brazing time at $950^{\circ} \mathrm{C}$, the contact between $\mathrm{TiAl}$ and $\mathrm{AlCu}_{2} \mathrm{Ti}$ phase results in interdiffusion between them. Based on the $\mathrm{Al}-\mathrm{Cu}-\mathrm{Ti}$ ternary alloy phase diagram shown in Fig. 4(a), TiAl and $\mathrm{AlCu}_{2} \mathrm{Ti}$ phase do not share a boundary curve [30]. On the other hand, $\mathrm{AlCu}_{2} \mathrm{Ti}$ and AlCuTi do share a boundary curve, 


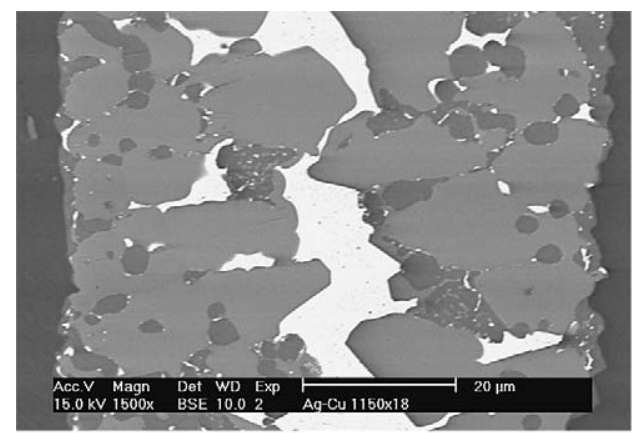

(a)

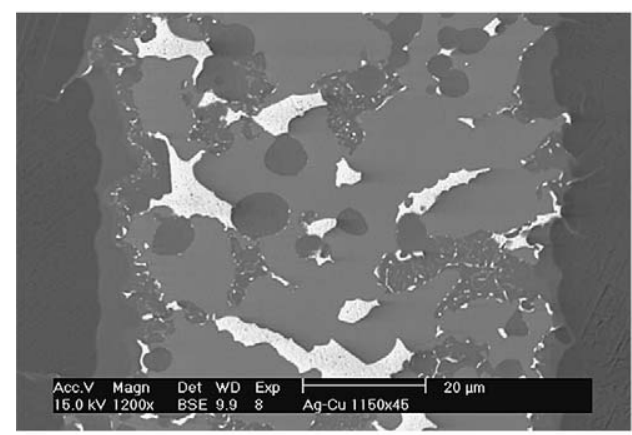

(c)

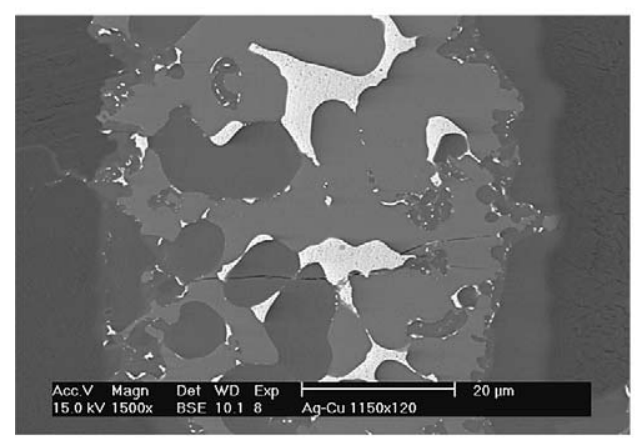

(e)

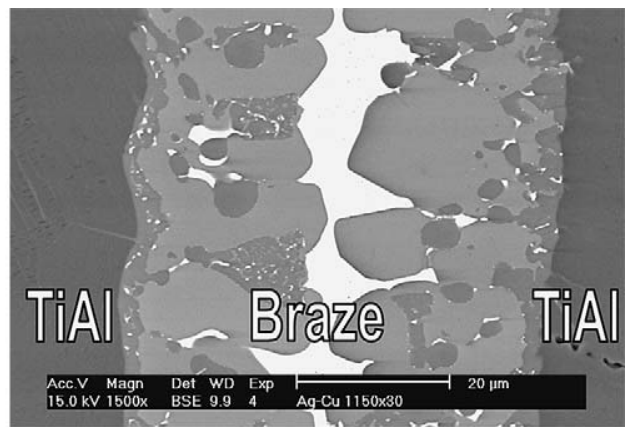

(b)

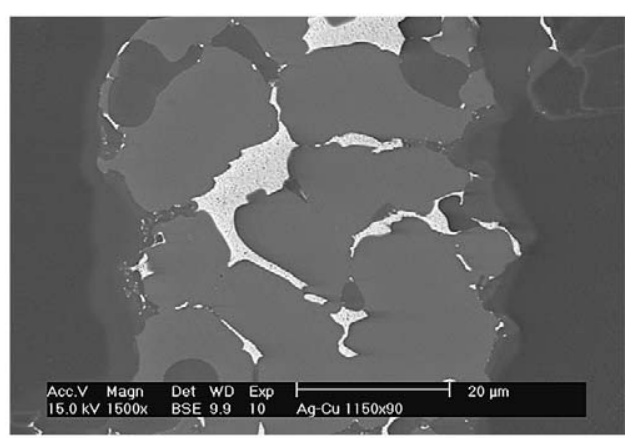

(d)

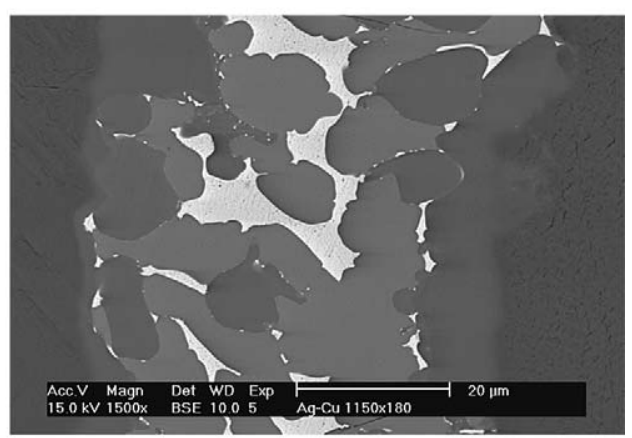

(f)

Fig. 8. SEM BEIs of the TiAl/BAg-8/TiAl specimen brazed at $1150^{\circ} \mathrm{C}$ for (a) 15 (b) 30 (c) 45 (d) 90 (e) 120 and (f) $180 \mathrm{~s}$.

so it is reasonable that AlCuTi phase is observed at the interface, as shown in Fig. 2(c-f).

For the specimen brazed at $1050{ }^{\circ} \mathrm{C}$, the dissolution of TiAl is greatly enhanced compared to the specimen brazed at $950^{\circ} \mathrm{C}$, so the molten braze dissolves much more titanium and aluminum. There is a binary eutectic reaction $\left(\mathrm{e}_{1}\right)$ at $1100^{\circ} \mathrm{C}$ in Fig. 4(a) [30]:

$\mathrm{L} \leftrightarrow \mathrm{AlCuTi}+\mathrm{AlCu}_{2} \mathrm{Ti}$
The chemical composition of liquid in equation (2) is $46 \mathrm{Cu}, 28 \mathrm{Al}$ and $26 \mathrm{Ti}$ in at pct, and the liquid phase dissolves much more aluminum and titanium due to the higher brazing temperature. Both $\mathrm{AlCuTi}$ and $\mathrm{AlCu}_{2} \mathrm{Ti}$ interfacial phases are observed, as illustrated in Fig. 7, so it is consistent with equation (2). If the cooling path follows the boundary curve between $\mathrm{AlCuTi}$ and $\mathrm{AlCu}_{2} \mathrm{Ti}$ phase, the residual liquid moves from $\mathrm{e}_{1}$ towards to the invariant reaction $U_{8}$ in Fig. 4(a). The transition reaction $\mathrm{U}_{8}$ can be shown below [30]: 


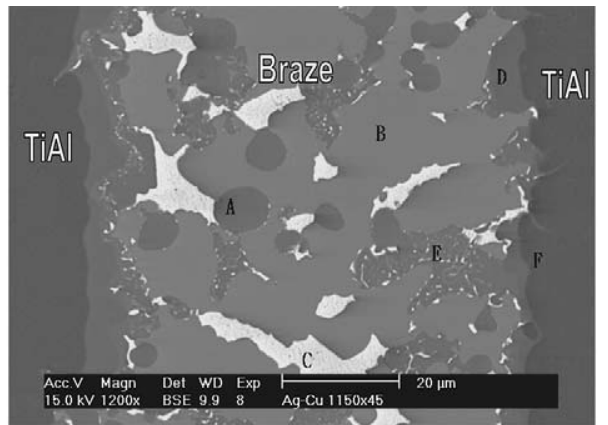

\begin{tabular}{|c|c|c|c|c|c|c|}
\hline $\mathrm{Wt} \% / \mathbf{A t} \%$ & $\mathrm{~A}$ & $\mathrm{~B}$ & $\mathrm{C}$ & $\mathrm{D}$ & $\mathrm{E}$ & $\mathrm{F}$ \\
\hline $\mathrm{Ti}$ & $67.6 / \mathbf{5 9 . 4}$ & $37.9 / 35.7$ & $0.5 / \mathbf{1 . 0}$ & $59.0 / 49.6$ & $60.5 / \mathbf{5 5 . 1}$ & $63.8 / \mathbf{4 9 . 9}$ \\
\hline $\mathrm{Al}$ & $23.1 / \mathbf{3 6 . 0}$ & $22.8 / \mathbf{3 8 . 2}$ & $2.7 / 9.7$ & $30.4 / \mathbf{4 5 . 4}$ & $21.6 / 35.0$ & $35.9 / \mathbf{4 9 . 9}$ \\
\hline $\mathrm{Cu}$ & $3.4 / 2.3$ & $33.2 / 23.6$ & $3.0 / 4.6$ & $4.4 / 2.8$ & $9.1 / 6.3$ & $0.2 / \mathbf{0 . 1}$ \\
\hline $\mathrm{Ag}$ & $5.9 / 2.3$ & $6.1 / \mathbf{2 . 5}$ & $93.8 / \mathbf{8 4 . 7}$ & $6.2 / \mathbf{2 . 3}$ & $8.8 / 3.6$ & $0.1 / \mathbf{0 . 1}$ \\
\hline $\begin{array}{c}\text { Possible } \\
\text { Phase }\end{array}$ & $\mathrm{Ti}_{3} \mathrm{Al}$ & $\mathrm{AlCuTi}$ & Ag-rich & $\mathrm{TiAl}$ & $\mathrm{Ti}_{3} \mathrm{Al}$ & $\mathrm{TiAl}$ \\
\hline
\end{tabular}

Fig. 9. SEM BEI and EPMA chemical analysis results of the $\mathrm{TiAl} / \mathrm{BAg}-8 / \mathrm{TiAl}$ specimens brazed at $1150^{\circ} \mathrm{C}$ for $45 \mathrm{~s}$.

$\mathrm{L}+\mathrm{AlCu}_{2} \mathrm{Ti} \leftrightarrow \mathrm{AlCuTi}+\mathrm{Al}_{4} \mathrm{Cu}_{9}$

As written, it is a four phase reaction. All three phases, $\mathrm{AlCu}_{2} \mathrm{Ti}, \mathrm{AlCuTi}$ and $\mathrm{Al}_{4} \mathrm{Cu}_{9}$, can be observed in Figs. 6 and 7, so it is consistent with the experimental observation.

Fig. 10 shows the isothermal section of Ag-Al$\mathrm{Ti}$ at $1000^{\circ} \mathrm{C}$ and $\mathrm{Ag}-\mathrm{Cu}-\mathrm{Ti}$ at $1005^{\circ} \mathrm{C}$, respectively [30]. This figure demonstrates that the Agrich liquid can dissolve much more aluminum and copper than titanium. Therefore, the aluminum content is depleted from $\mathrm{TiAl}$ substrate, and $\mathrm{Ti}_{3} \mathrm{Al}$ is formed at the interface between AlCuTi and TiAl, as shown in Fig. 7. In addition, there is a composition triangle of TiAl-AlCuTi-Ti ${ }_{3} \mathrm{Al}$ in Fig. 4(b), so the experimental observation is in accordance with the ternary phase diagrams.

It is expected that the dissolution of TiAl substrate into the molten braze reaches a maximum for the specimen infrared brazed at $1150^{\circ} \mathrm{C}$. There is a peritectic reaction, $\mathrm{P}_{2}$, shown below [30]:

$\mathrm{L}+\mathrm{AlTi}+(?) \mathrm{AlTi}_{3} \leftrightarrow \mathrm{AlCuTi}$

As written, it is a four phase reaction. The question mark in equation (4) stands for uncertainty of the reaction. The chemical composition of the liquid (a)

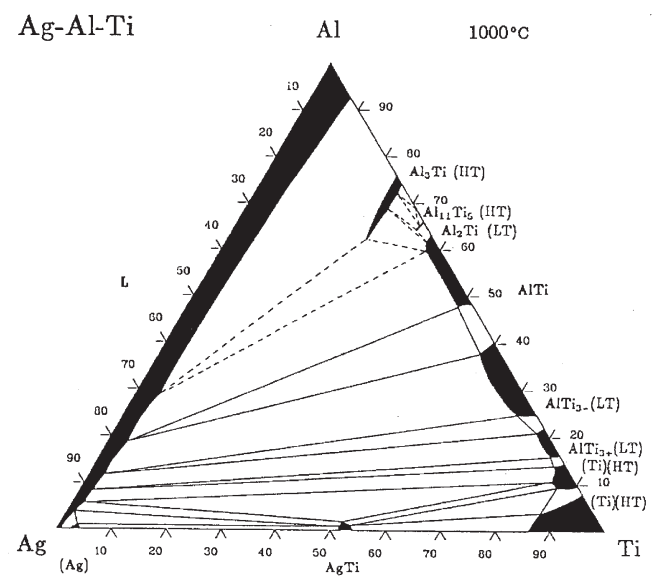

(b)

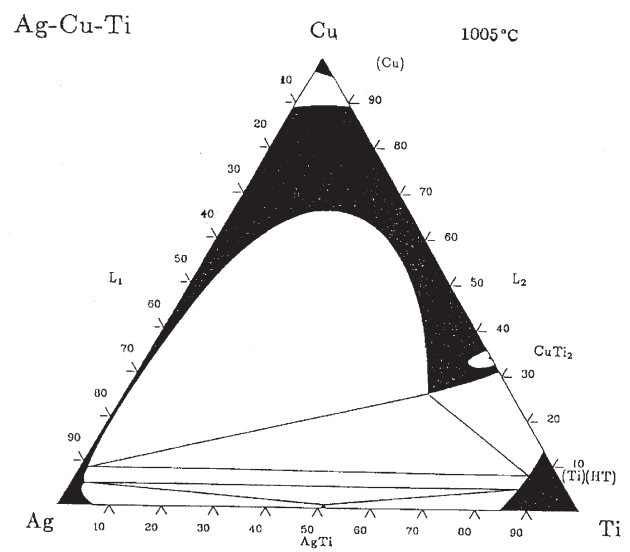

Fig. 10. Isothermal section of (a) Ag-Al-Ti phase diagram at $1000^{\circ} \mathrm{C}$ and (b) Ag-Cu-Ti phase diagram at $1005^{\circ} \mathrm{C}[30]$.

shown in equation (4) is $15 \mathrm{Cu}, 40 \mathrm{Al}$ and $45 \mathrm{Ti}$ in at pct, so there are huge amounts of titanium and aluminum dissolved in the molten braze. Equation (4) is consistent with our experimental observation. Moreover, the composition triangle of TiAl-AlCuTi-Ti ${ }_{3} \mathrm{Al}$ shown in Fig. 4(b) indicates that these phases can coexist.

Based on the information from the Al-Cu-Ti ternary phase diagram, the microstructural evolution of the brazed joint can be elucidated. As the brazing temperature increases from $950^{\circ} \mathrm{C}$ into $1150^{\circ} \mathrm{C}$, the dissolution of $\mathrm{TiAl}$ substrate into the molten braze is significantly enhanced. Both titanium and aluminum contents in the molten braze also increase as increasing the brazing temperature. 
Therefore, it is reasonable that the chemical composition of the molten braze at $950^{\circ} \mathrm{C}, 1050^{\circ} \mathrm{C}$ and $1150^{\circ} \mathrm{C}$ can be approximated by points $\mathrm{e}_{2}, \mathrm{e}_{1}$ and $\mathrm{P}_{2}$ in Fig. 4(a), respectively. Most phases observed in the SEM observations fit well with the $\mathrm{Al}-\mathrm{Cu}$ Ti phase diagram.

\subsection{Mechanical evaluation of the infrared brazed TiAl/BAg-8/TiAl}

Fig. 11 shows Vickers microhardness measurements of various phases in the TiAl/BAg-8/TiAl joint. According to the experimental results, the residual Ag-rich filler metal is very soft compared with all other phases. All reaction layers, $\mathrm{Ti}_{3} \mathrm{Al}$, $\mathrm{AlCuTi}$ and $\mathrm{AlCu}_{2} \mathrm{Ti}$, are harder than the TiAl substrate, and the AlCuTi phase demonstrates the highest microhardness among all phases in the joint. It is well known that the interfacial microstructure is strongly related to the bonding strength of the joint. Consequently, widespread existence of

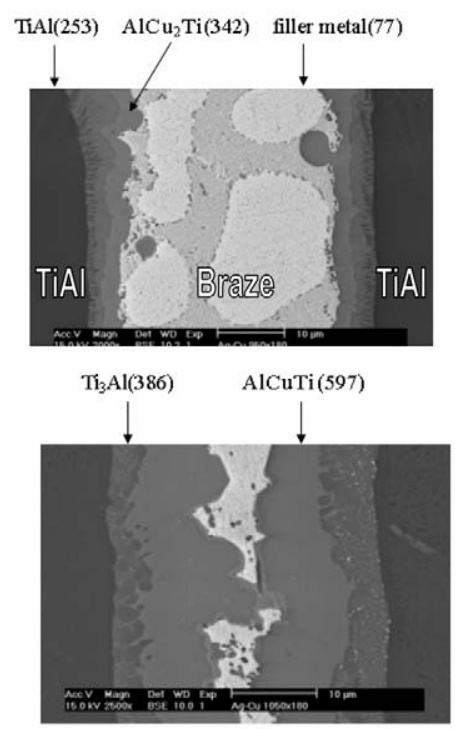

\begin{tabular}{|c|c|c|c|c|c|}
\hline Phase & TiAl & $\mathrm{Ti}_{3} \mathrm{Al}$ & $\mathrm{AlCuTi}$ & $\mathrm{AlCu}_{2} \mathrm{Ti}$ & Ag-rich Filler \\
\hline Hardness (Hv) & 253.8 & 385.9 & 597.3 & 342.8 & 76.8 \\
\hline Standard Deviation & 12.4 & 10.5 & 22.3 & 18.5 & 7.7 \\
\hline
\end{tabular}

Fig. 11. Microhardness measurements of various phases across the TiAl/BAg-8/TiAl joint. a hard AlCuTi phase can result in deterioration of its bonding strength.

Fig. 12 shows the shear strength of specimens brazed at $950^{\circ} \mathrm{C}$ for different time periods. The shear strength is not satisfactory for a very short brazing time, e.g. $30 \mathrm{~s}$, and the maximum shear stress, $343 \mathrm{MPa}$, is obtained for the specimen infrared brazed at $950^{\circ} \mathrm{C}$ for $60 \mathrm{~s}$. Further increase of the brazing time will result in constant deterioration of its bonding strength, and the shear strength is decreased to $277 \mathrm{MPa}$ for the specimen brazed at $950^{\circ} \mathrm{C}$ for $180 \mathrm{~s}$.

Cross sections of above fractured specimens are mounted in an epoxy, and examined by an SEM. Fig. 13 shows the cross section of $\mathrm{TiAl} / \mathrm{BAg}$ 8/TiAl joint after shear test infrared brazed at $950^{\circ} \mathrm{C}$ for 60,120 and $180 \mathrm{~s}$. Since the sample was broken after shear test, only one of the broken pieces was chosen for SEM failure analysis. Based on the Fig. 13, the fracture location changes from $\mathrm{Ag}-\mathrm{Cu}$ eutectic braze into the interfacial reaction interlayer as the brazing time increases from 60 to 180 s. The crack can be observed clearly in the $\mathrm{Ag}-\mathrm{Cu}$ eutectic braze after shear test as presented in Fig. 13(a). However, cracks along the interface are observed for specimens brazing at $950^{\circ} \mathrm{C}$ for 120 and 180 s. As discussed earlier, there are many reaction layers in the joint, so it is necessary to perform analysis in greater depth to understand relations between the interfacial reaction layer and bonding strength.

Fig. 14 shows the X-ray structural analyses of the fracture surface after shear test for specimens

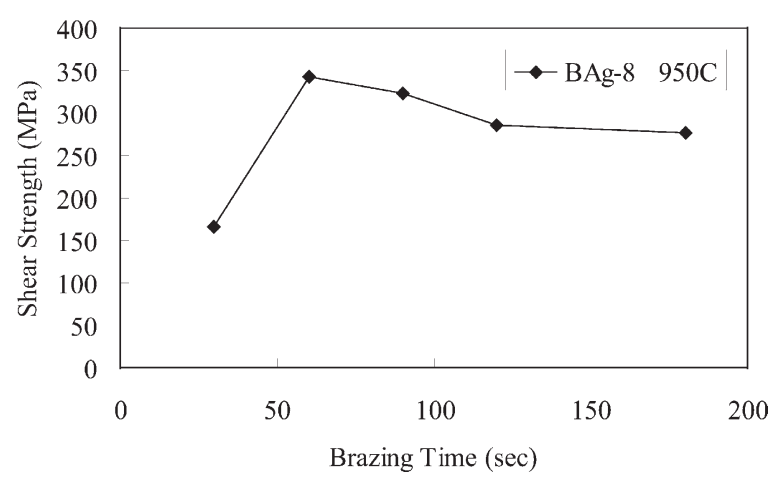

Fig. 12. Shear strength of the TiAl intermetallic specimens brazed at $950^{\circ} \mathrm{C}$ for various time periods. 


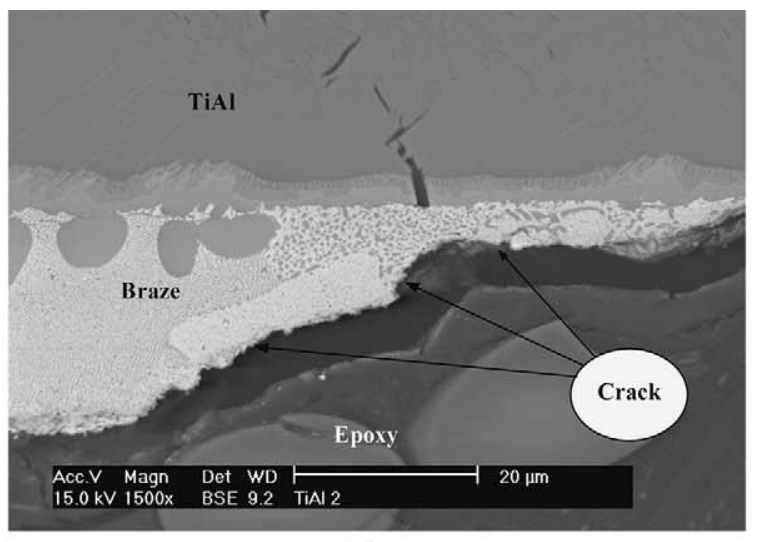

(a)

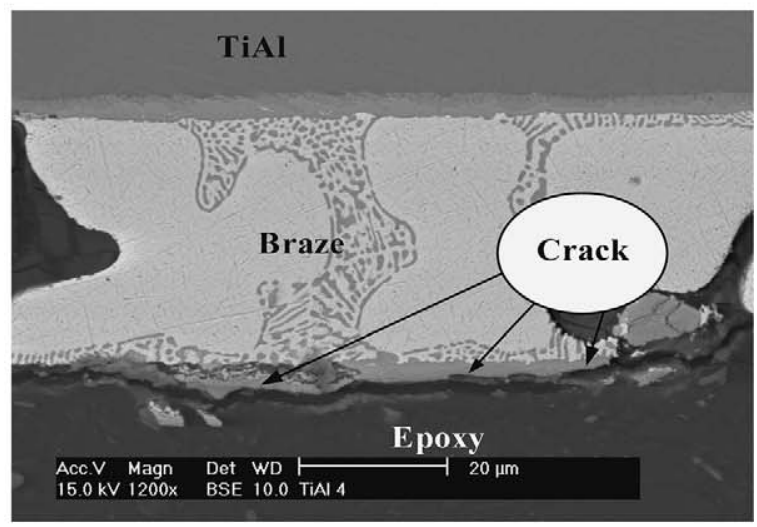

(b)

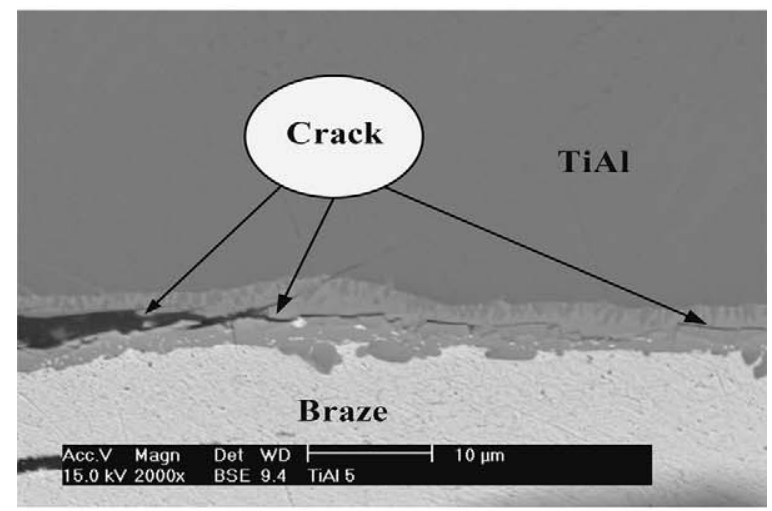

(c)

Fig. 13. Cross section of TiAl/BAg-8/TiAl joint after shear test infrared brazed at $950^{\circ} \mathrm{C}$ for (a) 60 (b) 120 and $180 \mathrm{~s}$. infrared brazed at $950^{\circ} \mathrm{C}$ for $30,60,120$ and 180 $\mathrm{s}$. It is clear that both silver and copper are widely observed in the specimen infrared brazed at $950^{\circ} \mathrm{C}$ for 30 and $60 \mathrm{~s}$. With increasing the brazing time, the $\mathrm{Ag}-\mathrm{Cu}$ eutectic phase disappears due to growth of the interfacial reaction layers, which is in accordance with the aforementioned results. On the other hand, there are strong $\mathrm{AlCuTi}\left(\mathrm{Ti}(\mathrm{Cu}, \mathrm{Al})_{2}\right)$ peaks found in the XRD analyses of the specimen infrared brazed at $950^{\circ} \mathrm{C}$ for over $120 \mathrm{~s}$. The XRD analyses confirm that excessive growth of AlCuTi reaction layer is detrimental to its bonding strength.

\section{Conclusions}

Microstructural evolution, bonding strength and the reaction path of infrared brazed TiAl intermetallics using BAg- 8 braze alloy are experimentally assessed. The primary conclusions can be summarized as below.

1. According to the experimental observation, silver will not react with the TiAl substrate, but copper will react vigorously with the TiAl forming continuous reaction layers. The consumption of copper from molten braze during infrared brazing results in depletion of the copper content in braze. Therefore, chemical composition of the braze deviates from the $\mathrm{Ag}-\mathrm{Cu}$ eutectic into hypoeutectic with increased brazing time and/or temperature.

2. Both $\mathrm{AlCuTi}$ and $\mathrm{AlCu}_{2} \mathrm{Ti}$ phase are observed at the interface between BAg-8 and TiAl substrate. However, the growth rate of $\mathrm{AlCuTi}$ phase is much faster than that of $\mathrm{AlCu}_{2} \mathrm{Ti}$ phase with increased brazing temperature and time. It is noted that there is $\mathrm{Ti}_{3} \mathrm{Al}$ phase observed in the joint. This occurrence is because the Ag-rich liquid can dissolve much more aluminum and copper than titanium, so the aluminum content is fast depleted from $\mathrm{TiAl}$ substrate, and $\mathrm{Ti}_{3} \mathrm{Al}$ is formed at the interface of AlCuTi and TiAl. Most phase evolution across the brazed joint can be explained by $\mathrm{Al}-\mathrm{Cu}-\mathrm{Ti}$ ternary alloy phase diagram.

3. Microhardness measurements demonstrate that 


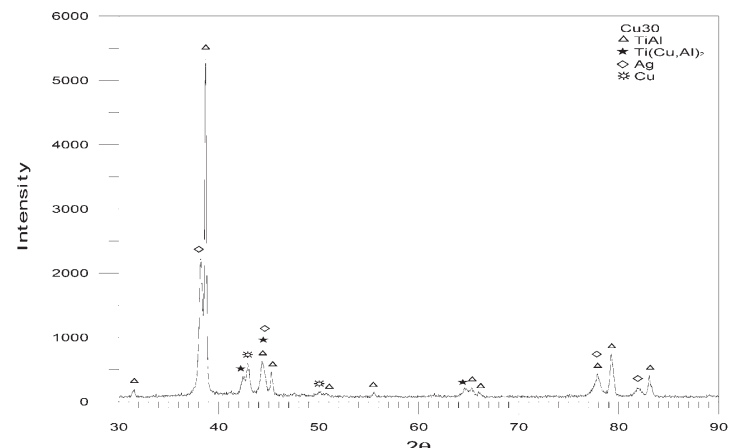

(a)

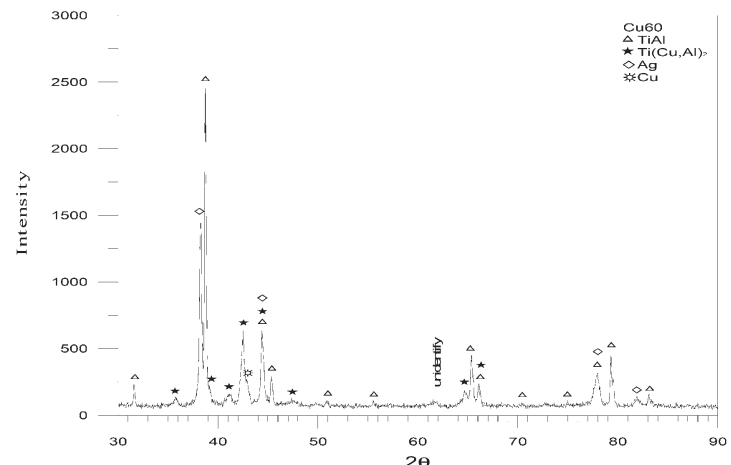

(b)

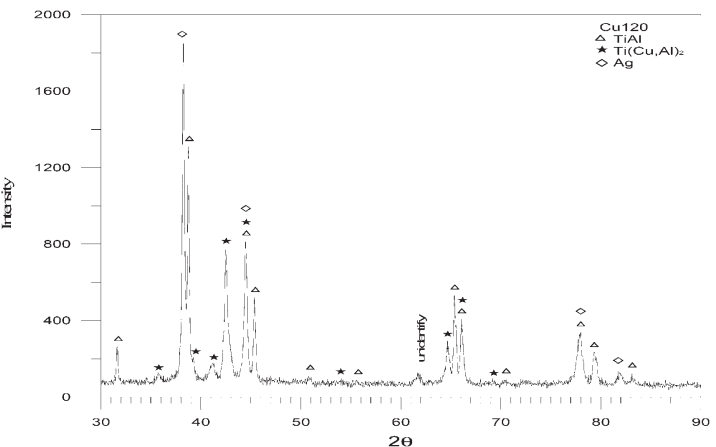

(c)

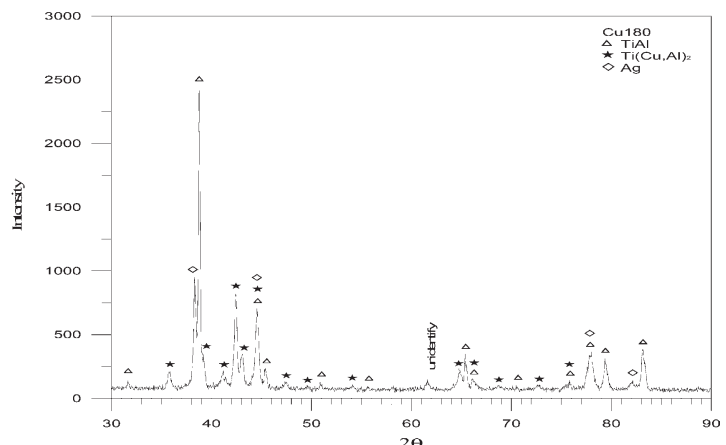

(d)

Fig. 14. X-ray structural analysis of the fracture surface after shear test for specimens infrared brazed at $950^{\circ} \mathrm{C}$ for (a) 30 (b) 60 (c) 120 and (d) $180 \mathrm{~s}$.

the residual Ag-rich filler is very soft compared with all other phases. All reaction layers, $\mathrm{Ti}_{3} \mathrm{Al}$, $\mathrm{AlCuTi}$ and $\mathrm{AlCu}_{2} \mathrm{Ti}$, are harder than the TiAl substrate, and AlCuTi phase demonstrates the highest microhardness among all phases in the joint.

4. The maximum shear strength is $343 \mathrm{MPa}$ for the specimen brazed at $950^{\circ} \mathrm{C}$ for $60 \mathrm{~s}$. Further increasing the brazing time results in excessive growth of brittle AlCuTi reaction layer, which greatly deteriorates the shear strength of the joint. The fracture location changes from $\mathrm{Ag}-\mathrm{Cu}$ eutectic braze into the interfacial reaction layer as the brazing time increases from 60 to $180 \mathrm{~s}$. The aforementioned observation is also confirmed by XRD analysis of the fractured surface in the brazed specimen.

\section{Acknowledgements}

The authors gratefully acknowledge the financial support from National Science Council (NSC), Republic of China, under the grant NSC 89-2216E002-071.

\section{References}

[1] Palm M, Zhang LC, Stein F, Sauthoff G. Intermetallics 2002; 10:523.

[2] Djanarthany S, Viala JC, Bouix J. Mater. Chem. Phys 2001;72:301.

[3] Moll JH, McTiernan BJ. Metal Powder Report 2000;55:18.

[4] Liu CT, Maziasz PJ. Intermetallics 1998;6:653.

[5] Liu CT, Schneibel JH, Maziasz PJ, Wright JL, Easton DS. Intermetallics 1996;4:429. 
[6] Yamaguchi M, Inui H, Ito K. Acta Mater 2000;48:307.

[7] Gorzel A, Sauthoff G. Intermetallics 1999;7:371.

[8] Johnson DR, Lee HN, Muto S, Yamanaka T, Inui H, Yamaguchi M. Intermetallics 2001;9:923.

[9] Morris MA, Leboeuf M. Intermetallics 1997;5:339.

[10] Song Y, Xu DS, Yang R, Li D, Hu ZQ. Intermetallics 1998;6:157.

[11] Izumi $T$, Yoshioka $T$, Hayashi S, Natita T. Intermetallics 2002;10:353.

[12] Tetsui T, Ono S. Intermetallics 1999;7:689.

[13] Srivastava D, Chang ITH, Loretto MH. Materials and Design 2000;21:425.

[14] Haanappel VAC, Sunderkotter JD, Stroosnijder MF. Intermetallics 1999;7:529.

[15] Taniguchi S, Uesaki K, Zhu YC, Matsumoto Y, Shibata T. Mater. Sci. Eng. 1999;A266:267.

[16] Noda T, Shimizu T, Okabe M, Iikubo T. Mater. Sci. Eng. 1997;613:A239-A40.

[17] Tetsui T. Intermetallics 2001;9:253.

[18] Holmquist M, Recina V, Pettersson B. Acta Metall. Mater 1999;47:1791.

[19] Blue CA, Warrier SG, Robson MT, Lin RY. Welding J 1993;6:51.
[20] Blue CA, Blue RA, Lin RY. Process Adv. Mater 1994;9:141.

[21] Nakao Y, Shinozaki K, Hamada M. ISIJ Int 1991;31:1260.

[22] Shiue RK, Wu SK, O JM, Wang JY. Metall. Mater. Trans 2000;31A:2527.

[23] Yang TY, Wu SK, Shiue RK. Intermetallics 2001;9:341.

[24] Shiue RK, Wu SK, Hung CM. Metall. Mater. Trans 2002;33A: 1765.

[25] Dececco NA, Parks JN. Welding J 1953;32:1071.

[26] Tiner NA. Welding J 1955;34:846.

[27] Olson DL, Siewert TA, Liu S, Edwards GR. ASM handbook (vol 6). Materials Park, OH: ASM International, 1993 pp 938.

[28] Humpston G, Jacobson DM. Principles of soldering and brazing. Materials Park, OH: ASM International, 1993 pp 34.

[29] Massalski TB. Binary alloy phase diagrams. Materials Park, OH: ASM International, 1990.

[30] Villars P, Prince A, Okamoto H. Handbook of Ternary Alloy Phase Diagrams. Materials Park, OH: ASM International, 1995. 